\title{
PROBIOTICS AS FOOD SUPPLEMENTS
}

\section{PROBIOTICI KAO DODACI U ISHRANI}

\author{
Danka Đorović', Miloš Maksimović', Đorđe Radak²,
}

\section{Summary}

Many studies have shown that the use of probiotics acts positively on a disturbed intestinal ecosystem. Probiotics are defined as living, non-pathogenic microorganisms (usually bacteria), which confer a health benefit on the host when administrated in adequate amounts. Probiotics mechanisms described so far include adhesion to the surface of intestinal epithelium, competition with pathogens for receptors and nutrients, improvement of mucosal barrier function and maintenance of intestinal integrity, promotion of innate and acquired immune response, elaboration of bactericins and modulation of cellular kinetics. Dysbiosis of endogenous microbiota can lead to compromised immune responses and manifestations of various autoimmune diseases. Even some local and systemic metabolites of probiotic have been identified to have anti-inflammatory activity and may modify autoimmune diseases. The list of diseases that can benefit from the use of probiotics is long and includes acute diarrhea, urogenital infections, allergies, lactose intolerance, cystic fibrosis, carcinoma, inflammatory bowel disease, teeth and mouth disease, etc. The aim of this paper is to summarize the latest information from the currently available scientific literature on the role of probiotics in human health and disease.

Key words: probiotics, health benefits, diarrhea, allergies, obesity

\section{Sažetak}

Mnoga istraživanja su pokazala da primena probiotika deluje pozitivno na poremećeni intestinalni ekosistem. Probiotici su definisani kao živi, nepatogeni mikroorganizmi (uglavnom bakterije), koji kada se daju u dovoljnoj količini, ostvaruju pozitivan efekat na zdravlje domaćina. Mehanizmi dejstva probiotika, opisani do sada, uključuju adheziju za površinu intestinalnog epitela, kompeticiju sa patogenima za receptorska mesta i nutrijente, pobolǰsanje funkcije mukozne barijere i očuvanje intestinalnog integriteta, promociju urođenog i stečenog imunog odgovora, stvaranje baktericina i modulaciju ćelijske kinetike. Disbioza endogene mikrobiote može dovesti do kompromitovanih imunih odgovora i manifestacije različitih autoimunskih bolesti. Čak su identifikovani lokalni i sistemski metaboliti probiotika koji imaju antiinflamatorno dejstvo i koji mogu da modifikuju autoimunske bolesti. Lista bolesti koje mogu imati koristi od upotrebe probiotika je duga, i uključuje akutnu dijareju, urogenitalne infekcije, alergije, intoleranciju na laktozu, cističnu fibrozu, karcinome, inflamatorne bolesti creva, oboljenja zuba i usta itd. Cilj ovog rada je da rezimira najnovije informacije, iz trenutno dostupne naučne literature, o ulozi probiotika u ljudskom zdravlju i bolesti.

Ključne reči: probiotici, zdravstvene koristi, dijareja, alergije, gojaznost

\section{INTRODUCTION}

Health benefits of bacteria have been recognized throughout history. Fermented milk was consumed in the Middle East as early as 10,000 BC, followed by populations in Egypt (as evidenced by the hieroglyphs), ancient Greece and Rome. (1) During the time of Genghis Khan in the 12th century, fermented milk was considered as source of strength and health, and Mongolian women would spray horses and riders with it to protect them in the battles. Era of probiotics started with Elie Metchnikoff, a bacteriologist and Nobel Prize winner, who correlated the longevity of the Bulgarians and their high consumption of fermented milk at the beginning of the 20th century. The species Lactobacillus bulgaricus was named in his honor. At the same time, a French pediatrician HenryTissier, observed that infants presenting with diarrhea had few bifidobacteria in their stools whereas these bacteria were dominant in the stools of healthy infants.

The concept of beneficial bacteria which was forgotten during the era of antibiotics and vaccines, is again the interest of scientists, since intestinal microbiota plays a significant role in human health and disease. Dysbiosis of the intestinal ecosystem contributes to the development of many pathological conditions. Studies have shown that the use of probiotics acts positively on a disturbed intestinal ecosystem.

Probiotics are defined as living, non-pathogenic microorganisms (usually bacteria), which confer a health benefit on the host when administrated in adequate amounts. (2) Only a small number of bacteria meet this definition. Probiotics are primarily bacteria from the lactobacilli and bifidobacterium genera, however, other bacteria may also act as probiotics: Lactococcus, Streptococcus and Enterococcus species, some non-pathogenic strains of Escherichia coli, as well as certain strains of bacilli and yeasts. (3)

Nowadays, probiotic strains are applied widely due to proven health benefits in numerous randomized clinical trials. The list of diseases that can benefit from the use of probiotics is long and includes acute diarrhea, 
urogenital infections, allergies, lactose intolerance, cystic fibrosis, carcinoma, inflammatory bowel disease, teeth and mouth disease, etc.

Over the years, the scientific interest in discovering, evaluating and analyzing species with probiotic properties has grown intensively. The aim of this paper is to summarize the latest information from the currently available scientific literature on the role of probiotics in human health and disease.

\section{MECHANISMS OF THE ACTIVITY OF PROBIOTICS}

Probiotics mechanisms described so far include adhesion to the surface of intestinal epithelium, competition with pathogens for receptors and nutrients, improvement of mucosal barrier function and maintenance of intestinal integrity, promotion of innate and acquired immune response, elaboration of bactericins and modulation of cellular kinetics. (4)

Adhesion of bacteria to mucosal surfaces and epithelial cells is one of the key features of probiotic action. (5) Factors affecting probiotic adhesion include large surface proteins and mucus-binding proteins possessing regions homologous with binding domains of proteins such as lectins (6) For example, the species Lactococcus lactis has auto-aggregation phenotype and a mucin-binding protein $(\mathrm{MbpL})$ on its surface, which contributes to its adherent properties in the gut in vitro and in vivo.

The ability of probiotics to inhibit pathogen growth has been widely studied, and antimicrobial properties of probiotics have been recently described. Many probiotic species from the lactobacilli genera have shown great potential in vitro studies to inhibit certain intestinal pathogens such as Escherichia coli and Salmonella spp. (7) Several studies have discovered the ability of probiotics to secrete probiotic factors, such as bactericins, which have been shown to inhibit the adhesion and viability of known intestinal pathogens. (8) The species Lactobacillus reuteri forms a biofilm that produces a potent antimicrobial compound called reuterin, which has been shown to inhibit a wide spectrum of microorganisms.

Certain probiotic species have an effect on the function of the intestinal barrier too. The integrity of the intestinal barrier is influenced by changes in intestinal permeability, mucin composition and homeostasis between the production of new enterocytes and the rate of apoptosis of damaged enterocytes. Some probiotics have the potential to reduce the intestinal permeability by strengthening tight junctions between enterocytes and/or restoring the mucous layer. (4) The structural and functional properties of the mucin further affect the activity of bacterial adhesion.
Probiotics also affect cellular kinetics by acting on cell proliferation and apoptosis. The ability of certain probiotics to promote the propagation of normal cells and apoptosis of abnormal cells simultaneously, may have the potential to treat certain diseases such as cancer. (10)

In our intestines there is about $70 \%$ of the immune system known as GALT (gut-associated lymphoid tissue). The relationship between the intestinal microbiota and the immune system of the host was extensively examined. Dysbiosis of endogenous microbiota can lead to compromised immune responses and manifestations of various autoimmune diseases. Even some local and systemic metabolites of probiotic have been identified to have anti-inflammatory activity and may modify autoimmune diseases. These mechanisms are presented in Scheme 1.

\section{HeAlth benefits of PROBiotics}

Among the first indications for the use of probiotics were diarrhea, inflammatory bowel disease and allergy, before the list of indications spread to other diseases.

Infectious diarrhea. One of the first recommendations for probiotics use was the treatment and /or prevention of infectious diarrhea. Numerous studies have revealed significant benefit of probiotics in acute infectious diarrhea, with a reduction in diarrhea duration and in the number of stools. (11) Three randomized controlled clinical trials involving more than 1000 children, have proved a decrease in nosocomial diarrhea caused by rotavirus, in children treated with Lactobacillus GG probiotic. (12) Antibiotic-associated diarrhea due to antibiotic-induced dysbiosis is also an indication for the use of probiotics. The most common cause of this diarrhea is Clostridium difficile whose spores are often resistant to antibiotics. The results of one meta-analyze showed the efficacy of probiotics in the prevention of $C$. difficile diarrhea, but not the reduction of its incidence. (13)

Inflammatory bowel disease. In addition to genetics, epigenetics and immune responses of the host, many authors suggest the intestinal microbiota to be one of the causes of inflammatory bowel disease (IBD) too. This possible association led to an increased interest in probiotics use in patients with IBD. The results of many studies have demonstrated the inefficiency of probiotics in patients with Crohn's disease. $(14,15)$ On the other hand, it has been found that some probiotics are effective in ulcerative colitis, leading to induction of remission or its prolonged duration. (16) In 2017, Derwa et al. showed that the probiotic VSL \# 3 (containing lactobacilli, bifidobacilli, and Streptococcus thermophilus) can be as effective as 5-ASAs in preventing relapse of UC. (17) 


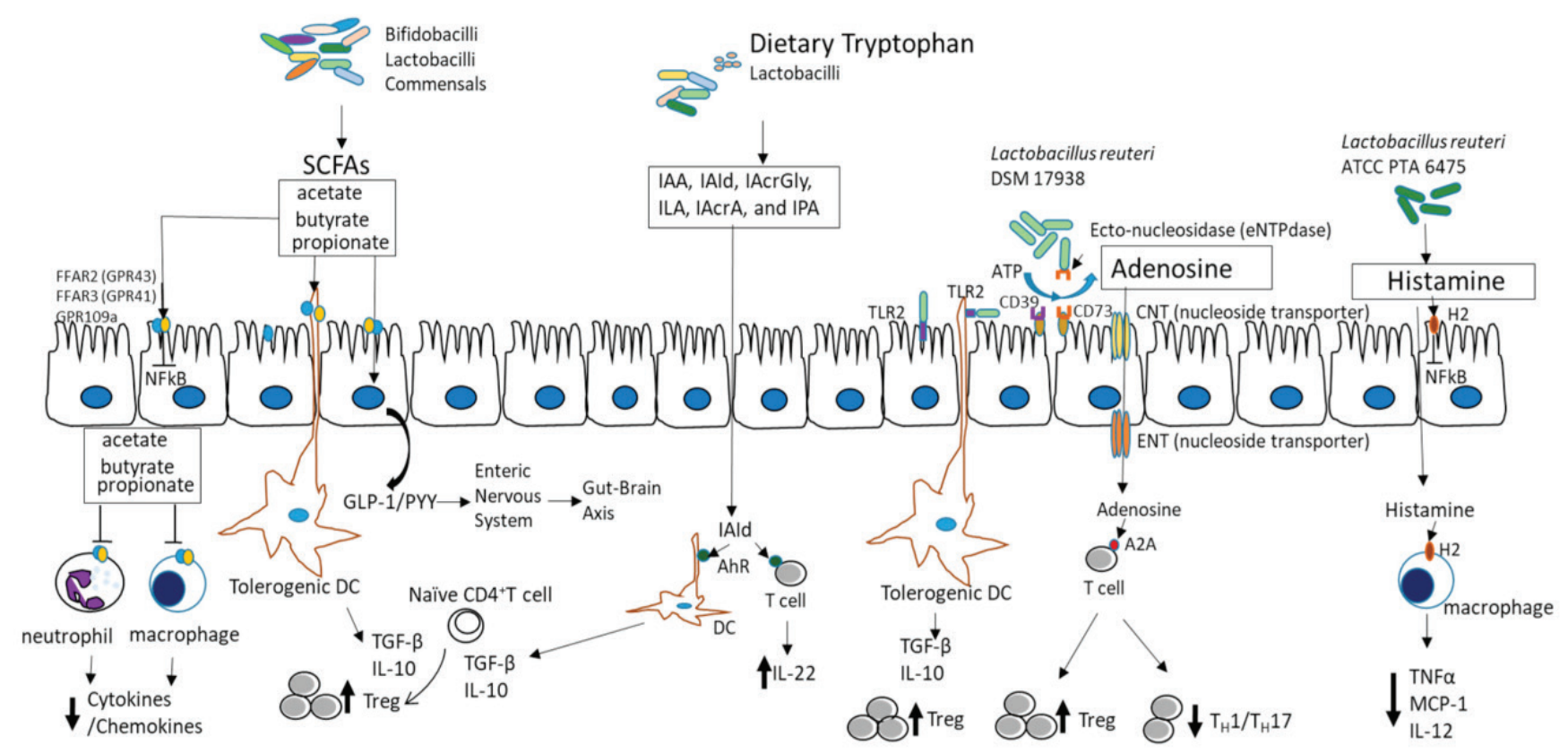

Reduced Inflammation

Shema 1. Critical metabolites produced by probiotics which have anti-inflammatory functions. Abbreviations. SCFAs: short-chain fatty acids; FFARs: free fatty acid receptors; GPRs: G-binding protein receptors; NF-KB: nuclear factor kappa-light-chain-enhancer of activated B cells; GLP1: glucagon-like protein-1; PYY: peptide tyrosine tyrosine; CNS: central nervous system; AhR: aryl hydrocarbon receptor; TH1 and TH17: T helper cells; H2: histamine receptor 2; TNF-a: tumor necrosis factor alpha; MCP-1: monocyte chemoattractant protein-1; IL-12: interleukin-12 (illustration by Yuying Liu)

Allergies. The probiotic efficacy for prevention of some allergic diseases, most frequently in high risk families, was of interest to many researchers. (18) The influence of Lactobobacillus $G G$ probiotics in patients with atopic dermatitis was investigated most extensively. One study showed a $50 \%$ reduction in the frequency of atopic dermatitis in children during the first two years, whose mothers took Lactobacillus GG capsules 2-4 weeks before and 6 months after delivery date, compared to placebo. (19) The evidence for use of probiotics as a preventative or therapeutic agent for respiratory allergies appears low. Although earlier studies have shown that Lactobacillus GG probiotic led to suppression of hyperreactivity of respiratory tract to methacholine and inhibition of inflamatory cell infiltration, in later studies these results could not be reproduced under similar circumstances, so current evidence does not support the use of probiotic in prevention of asthma. Furthermore, there is no strong evidence currently that probiotics influence the development of allergic rhinitis (20), as some studies indicated even increased prevalence of allergic rhino-conjunctivitis in those using probiotics perinatal and in early childhood. (21)

Obesity and diabetes mellitus type 2 . The authors of some studies have reported relationship between microbiota and obesity, (22), as well as one with type 2 diabetes. (23) One of the explanations is the colic fermentation of food not digested by microbiota in the small bowel, which induced the production of metabolites such as short-chain fatty acids which are further ab- sorbed, thus allowing recovering energy. (24.25) So far, the authors of interventional studies have not proved any beneficial effect of probiotics on BMI. However, Qin et al. in their study have revealed that faecal metagenomic markers differentiated obese from non obese patients more easily than markers of the human genome, (23) and further investigations on modification of intestinal microbiota in the treatment of these diseases are necessary.

The authors of some studies have indicated the contribution of probiotics in the prevention of upper respiratory tract infections (26), the treatment of Helicobacter pylori infection (27), the prevention of dental caries (28), the prevention of necrotizing enterocolitis in preterm infants (29), in treatment of infant colic in neonates (30), as well as in many other indications, but with currently insufficiently solid evidence for their use.

\section{Conclusion}

It is currently acknowledged that the gut microbiota interacts with human health and that its modulation by probiotics is an interesting way to prevent some diseases. But the effectiveness has not been proven in too many indications, limiting the current recommendations for probiotic use. But, the rational and the encouraging results reported in some studies support further research on probiotics. 


\section{References}

1. McFarland LV. From yaks to yogurt: The history, development, and current use of probiotics. Clin Infect Dis. 2015; 60:S85-S90.

2. Reid G. The importance of guidelines in the development and application of probiotics. Curr Pharm Des. 2005; 11:11-16.

3. Borchers AT, Selmi C, Meyers FJ, Keen CL, Gershwin ME. Probiotics and immunity. J Gastroenterol. 2009; 44:26-46.

4. Howarth GS. Probiotic-derived factors: Probiotaceuticals? J Nutr. 2010; 140:229-230.

5. Lukic J, Strahinic I, Jovcic B, Filipic B, Topisirovic L, Kojic M, Begovic J. Different roles of lactococcal aggregation factor and mucin binding protein in adhesion to gastrointestinal mucosa. Appl Environ Microbiol. 2012; doi:10.1128/AEM.02141-02112.

6. Van Tassell ML, Miller MJ. Lactobacillus adhesion to mucus. Nutrients. 2011; 3:613-636.

7. Bujnakova D, Kmet V. Functional properties of Lactobacillus strains isolated from dairy products. Folia Microbiol. (Praha) 2012; 57:263267.

8. Howarth GS. Probiotic-derived factors: Probiotaceuticals? J Nutr. 2010; 140:229-230.

9. Jones SE, Versalovic J. Probiotic Lactobacillus reuteri biofilms produce antimicrobial and anti-inflammatory factors. BMC Microbiol. 2009; 9:35.

10. Howarth GS, Wang H. Role of Endogenous Microbiota, Probiotics and Their Biological Products in Human Health. Nutrients. 2013; 5:58-81.

11. Allen SJ, Martinez EG, Gregorio GV, Dans LF. Probiotics for treating acute infectious diarrhoea. Cochrane Database Syst Rev. 2010:CD003048

12. Szajewska H, Wanke M, Patro B. Meta-analysis: the effects of Lactobacillus rhamnosus GG supplementation for the prevention of healthcare-associated diarrhoea in children. Aliment Pharmacol Ther. 2011; 34:1079-87.

13. Goldenberg JZ, Ma SS, Saxton JD, Martzen MR, Vandvik PO, Thorlund K, et al. Probiotics for the prevention of Clostridium difficile-associated diarrhea in adults and children. Cochrane Database Syst Rev 2013; 5:CD006095.

14. Butterworth AD, Thomas AG, Akobeng AK. Probiotics for induction of remission in Crohn's disease. Cochrane Database Syst Rev2008:CD006634

15. Rahimi R, Nikfar S, Rahimi F, Elahi B, Derakhshani S, Vafaie M, et al. A meta-analysis on the efficacy of probiotics for maintenance of remission and prevention of clinical and endoscopic relapse in Crohn's disease. Dig Dis Sci. 2008; 53:2524-31.

16. Shen J, Zuo ZX, Mao AP. Effect of probiotics on inducing remission and maintaining therapy in ulcerative colitis, Crohn's disease, and pouchi- tis: Meta-analysis of randomized controlled trials. Inflamm Bowel Dis. $2014 ; 20: 21-35$

17. Derwa Y, Gracie DJ, Hamlin PJ, Ford AC. Systematic review with meta-analysis: The efficacy of probiotics in inflammatory bowel disease. Aliment Pharmacol Ther. 2017; 46:389-400.

18. Waligora-Dupriet AJ, Butel MJ. Microbiota and allergy: from dysbiosis to probiotics. In: Pereira C, editor. Allergic diseases-highlights in the clinic, mechanisms and treatment. Rijeka: Intech; 2012. p. 413-34.

19. Kalliomaki M, Salminen S, Arvilommi H, Kero P, Koskinen P, Isolauri E. Probiotics in primary prevention of atopic disease: a randomized placebo-controlled trial. Lancet. 2001; 357:1076-9.

20. Zuccotti G, Meneghin F, Aceti A, Barone G, Callegari ML, Di Mauro A, et al. Probiotics for prevention of atopic diseases in infants: Systematic review and meta-analysis. Allergy Eur J Allergy Clin Immunol. 2015; 70:1356-1371.

21. Cuello-Garcia C, Brozek JL, Fiocchi A, Pawankar R, Yepes-Nuñez JJ, Terracciano L, et al. Probiotics for the prevention of allergies: A systematic review and meta-analysis of randomized controlled trials. J Allergy Clin Immunol. 2015; 136:952-961.

22. Turnbaugh PJ, Ley RE, Mahowald MA, Magrini V, Mardis ER, Gordon JI. An obesity-associated gut microbiome with increased capacity for energy harvest. Nature. 2006; 444:1027-31.

23. Qin J, Li Y, Cai Z, Li S, Zhu J, Zhang F, et al. A metagenome-wide association study of gut microbiota in type 2 diabetes. Nature. 2012; 490:55-60.

24. Shen J, Obin MS, Zhao L. The gut microbiota, obesity and insulin resistance. Mol Aspects Med. 2013; 34:39-58.

25. Sanz Y, Rastmanesh R, Agostonic C. Understanding the role of gut microbes and probiotics in obesity: how far are we? Pharmacol Res. 2013; 69:144-55

26. Hao Q, Lu Z, Dong BR, Huang CQ, Wu T. Probiotics for preventing acute upper respiratory tract infections. Cochrane Database Syst Rev 2011: CD006895.

27. Szajewska H, Horvath A, Piwowarczyk A, Meta-analysis: the effects of Saccharomyces boulardii supplementation on Helicobacter pylori eradication rates and side effects during treatment. Aliment Pharmacol Ther. 2010; 32:1069-79.

28. Nase L, Hatakka K, Savilahti E, et al. Effect of long-term consumption of a probiotic bacterium, Lactobacillus rhamnosus GG, in milk on dental caries and caries risk in children. Caries Res. 2001; 35:412-20.

29. Alfaleh K, Bassler D. Probiotics for prevention of necrotizing enterocolitis in preterm infants. Cochrane Database Syst. Rev. 2008, CD005496.

30. Sung V, D’Amico F, Cabana MD, Chau K, Koren G, Savino F, et al. Lactobacillus reuteri to Treat Infant Colic: A Meta-analysis. Pediatrics. 2018; 141, e20171811. 